\title{
A Compct 5.8 GHz CPW Double Square Edge Antenna With BPF Stepped Impedance Resonator
}

\author{
Irfan Mujahidin \\ Antenna and Propagation Laboratory, \\ Electrical Engineering \\ University of Merdeka Malang \\ Malang, Indonesia \\ Irfan.mujahidin@unmer.ac.id
}

\begin{abstract}
This research proposes a $5.8 \mathrm{GHz}$ circular polarization double square edge antenna with band pass filter that used method stepped impedance resonator (BPF-SIR) structure for designing a compact integrated antenna with the filter. the double layer electromagnetic circuit structure is used to miniaturize antenna integrated with complex bandpass filter at $5.8 \mathrm{GHz}$ frequency operation. furthermore, a novel electromagnetic component has been developed to produce $5.8 \mathrm{GHz}$ antenna with good gain value. even this circuit have not complex configuration, and inexpensive material, especially for the premium-frequency.
\end{abstract}

Key words: square edge antenna, stepped impedance resonator, band pass filter.

\section{INTRODUCTION}

An electromagnetic circuit using microstrip structure is popular to use in the telecommunications system due to very compatible to integrate with other electronic components. microstrip structure mostly has two layers of a metallic material as a patch and a ground. therefore, microstrip structure with twolayer have advantages of antenna its relatively simple on manufacture, lightweight, easy to fabricate[1].

The structure using several micro electromagnetic strips more streamlined than a common electronic circuit due to it degrades the costs of energy to convert the power process from the electromagnetic circuit to the following electrical circuits[2][3]. Furthermore, on empirical experience, this structure is a good proof for implementation and can be a harness. With compact dimensions and has, an advanced-frequency electromagnetic circuit is also well of generating a high power-level of gain[4][5]. Even the suggest electromagnetic circuit is well at generating the under $-3 \mathrm{~dB}$ that is circular polarization of axial ratio so that it can accept both polarization horizontal and vertical transmittal waves.

In this manuscript, a compact electromagnetic circuit be composed of a $5.8 \mathrm{GHz}$ single line strip transmittal antenna with a connector through via holes, rectangular radiating element, stepped impedance resonator bandpass filter and double edge has been adopted as the ground of filter with additional through via holes[6]. cutting corners on the rectangular patch to provide circular of axial ratio value a compact dimension antenna for wireless component, sensor, and other applications. This research serves a not complex and effectual composition for designing a circular of axial ratio value antenna integrated Bandpass filter without complicated circuit design, implemented method and using inexpensive materials at advancedfrequency[7][8].

\section{Method AND DESIGN}

Table 1 and Figure 1 represents the geometrical of the proposed miniaturized $5.8 \mathrm{GHz}$ electromagnetic circuit. in Figure 1, single transmittal lines embedded with via hole of the quarter of a wave have been implemented using an epoxy laminate or fr 4 substrate with $0.8 \mathrm{~mm}$ of the thickness[9][10][11]. this via hole transmittal lines are serial to the transmission lines of stepped impedance resonator bandpass filter.

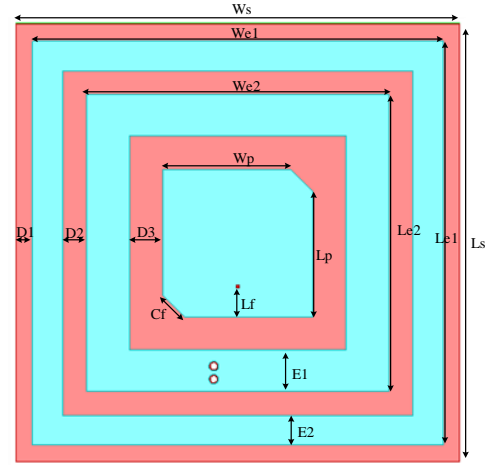

(a) 


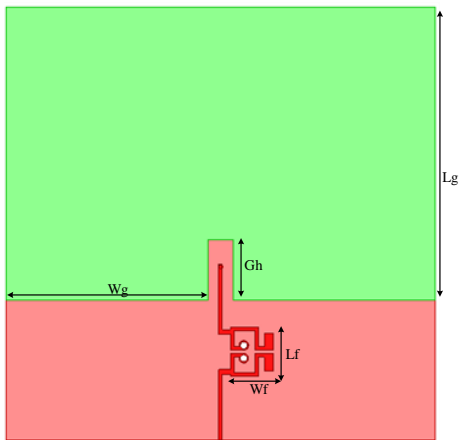

(b)

Figure 1. Structure 5.8 GHz CPW double square edge antenna with bpf stepped impedance resonator, (a) front side, and (b) back side

Table 1. Dimensions of structure

\begin{tabular}{|c|c|}
\hline Variable & Dimension (mm) \\
\hline $\mathrm{Ws}=\mathrm{Ls}$ & 40 \\
\hline We1 = Le1 & 34 \\
\hline $\mathrm{We} 2=\mathrm{Le} 2$ & 25 \\
\hline $\mathrm{Wp}=\mathrm{Lp}$ & 10.59 \\
\hline Lf & 3 \\
\hline $\mathrm{Cf}$ & 1.8 \\
\hline D1 & 1.5 \\
\hline D2 & 2 \\
\hline D3 & 2.8 \\
\hline E1 & 3.5 \\
\hline E2 & 2.66 \\
\hline Gh & 5.15 \\
\hline $\mathrm{Wg}$ & 17.3 \\
\hline $\mathrm{Lg}$ & 24.97 \\
\hline Lf & 4.2 \\
\hline Wf & 4.7 \\
\hline
\end{tabular}

On the rear antenna connected with bandpass filter stepped impedance resonator directly connected to the feeder circuit[12]. in this research, a single patch rectangular shape with cutting corners double edge used and connected to filter feed by thorough via hole so the primary shape is the rectangular radiation element, which is the dimensions patch radiation can be represented with the equation:

$$
W p=\frac{v_{0}}{2 f_{r}} \sqrt{\frac{2}{\epsilon_{r}+1}}
$$

This antenna using thin material that is FR4 so to maximal dimension for the approximate size value of the rectangular patch for circular polarization antenna can be determined with the equation :

$$
f \cong \frac{c}{2 W p \sqrt{\epsilon_{r}}}
$$

Where $\mathrm{Wp}$ is wide of radiation element, vo is the free-space velocity of the wave canal, $\mathrm{er}$ is the permittivity of relative dielectric on the ingredients of the substrate, the frequency of the electromagnetic circuit for implemented with notation is $\mathrm{f}$ and $\mathrm{fr}$ is the frequency resonance[13][14]. The circuit of microstrip design is a finished electromagnetic theory based on the literature and material composition defined[15].

To serve these requirements on $5.8 \mathrm{GHz}$, a Bend Pass Filter with a $5.8 \mathrm{GHz}$ band passed, wideband rejection and transmission zero should be included. Transmission zeros are the guide to correct band rejection and band passed as filter frequency picked. To describe the transmission zero, some developed methods have been done[16][17][18]. Basically, Transmission zeros can be represented by separate electric magnetic coupling methods, mixed electromagnetic coupling, and cross-coupling. A mixed electromagnetic coupling has been represented by scratching two coupled resonators with a top peak magnetic field and their top peak electric fields from the open gaps accurately, so to serve coupling coefficient On maximum dimension for the proximate size value of the bandpass filter stepped impedance resonator for circular polarization electromagnetic feed can be determined with the equation :

$$
K_{i, i+1}= \pm \frac{f_{2}^{2}-f_{1}^{2}}{f_{2}^{2}+f_{1}^{2}}
$$

Where the $f_{1}$ and $f_{2}$ are the two dominant resonant frequency.

\section{RESUlt AND PARAMETERS ANALYSIS}

Figure 2 refers to the enforcement of an electromagnetic circuit consisting of the antenna as a radiating element that has the main section they are patch connected with bandpass filter stepped impedance resonator feed by via hole and edge on the antenna as the ground of the bandpass filter[19]. The roundly dimension of the proposed electromagnetic circuit is $40 \mathrm{~mm} \times 40 \mathrm{~mm}$.

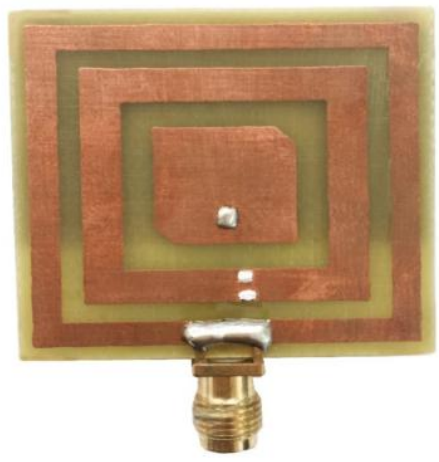

(a) 


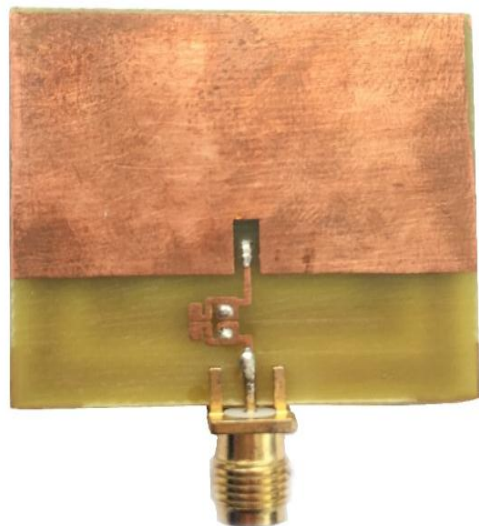

(b)

Figure 2. implementation of a $5.8 \mathrm{GHz}$ integrated rectangular cutting corners double edge microstrip antenna and bandpass filter stepped impedance resonator (a) front side, and (b) back side

To assign the frequency active of the integrated antenna and bandpass filter stepped impedance resonator, in Figure 4, it represents the return loss or s-parameter value of the integrated antenna and bandpass filter stepped impedance resonator as a reference[20].

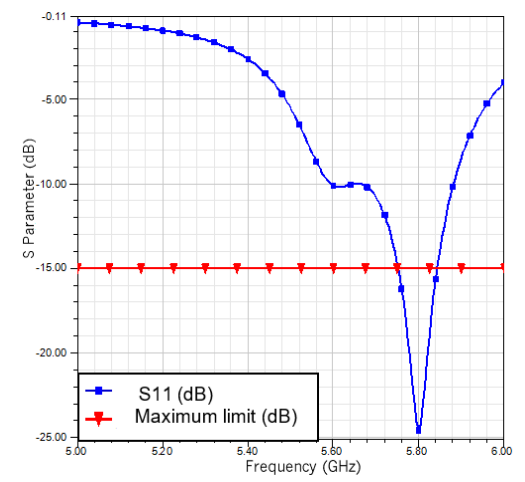

Figure 3. S parameter of the implementation of a rectangular cutting corners double edge microstrip antenna

The integrated antenna and bandpass filter stepped impedance resonator has good approval return loss or Sparameter grade that are $-24.56 \mathrm{~dB}$ on $5.8 \mathrm{GHz}$ and have represent of working frequency field $90 \mathrm{MHz}$ in under $15 \mathrm{~dB}$. with a narrow band, it can good support to integrate with a bandpass filter to reject wideband frequency[21].

To get the component plot coordinate of far of region field implementation of a rectangular cutting corner double edge antenna radiating region shape as a purpose of sphere spatial coordinates. It is important to represent the pattern of the radiating antenna region[22]. Figure 4. is the $5.8 \mathrm{GHz}$ rectangular cutting corners double edge radiation pattern of microstrip antenna:

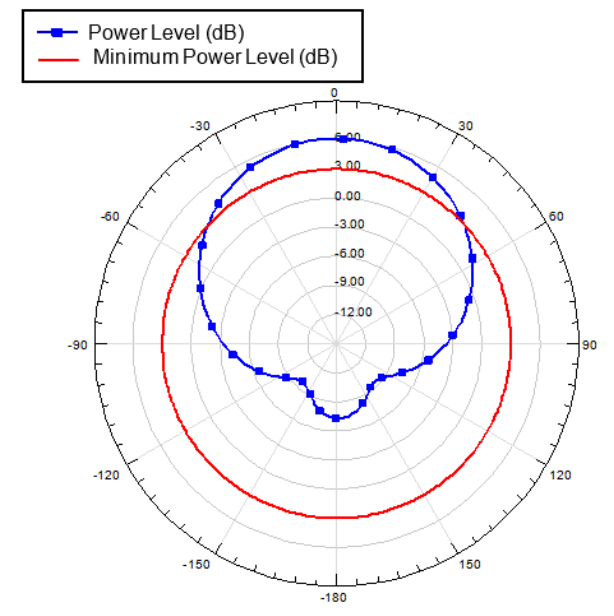

(a)

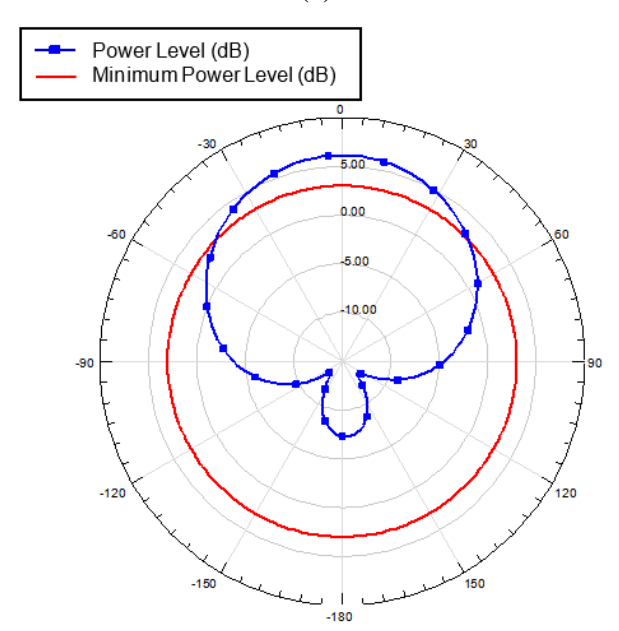

(b)

Figure 4. (a) Phi angles on the region of radiation pattern, and (b) Theta angles on the region of radiation pattern cutting corners double edge microstrip antenna

The radiation pattern of the analysis of the result has a good approval power level of the shape region and the power. the appearance of the region has a major lobe of the radiation pattern is biggest and has a so low-level back-lobe and side-lobe, it can be deduced that the cutting corners double edge microstrip antenna shape region radiation are directional[23]. To obtain the strengthening magnitude energy level in a specific major lobe to the cutting corners double edge microstrip antenna reference gain level consequently, need to know antenna power gain magnitude. Following gain value: 


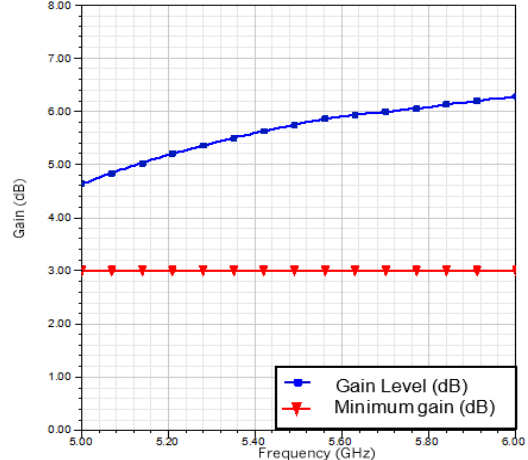

Figure 5. The gain level cutting corners double edge microstrip

Figure 5, it is an exhibit the power level of the gain microstrip antenna has a magnitude level of $6.29 \mathrm{dBi}$ on a frequency of $5.8 \mathrm{GHz}$. to assign on electromagnetic propagation of the E-field element and a lead wave of the cutting corners, a double edge microstrip antenna needs to describe the axial ratio. Following a graphic of axial ratio :

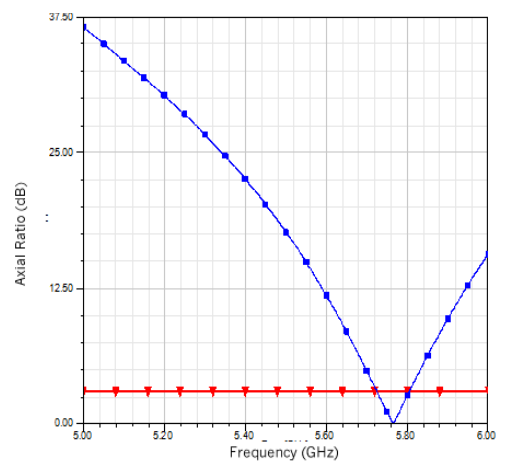

Figure 6. The axial ratio of cutting corners double edge microstrip antenna

Figure 6. shown the value of axial ratio cutting corners double edge microstrip antenna. In Figure 6 on $5.8 \mathrm{GHz}$ still under $3 \mathrm{~dB}$ of the axial ratio antenna level, it defines the e field electromagnetic propagation of antenna have circular polarization. The cutting corners double edge microstrip antenna $5.8 \mathrm{GHz}$ is manufactured using the same ingredient as the electromagnetic circuit is epoxy laminate with a low cost and convenient to obtain the substantial componenets. Figure. 8 shows the s parameter of the bandpass filter stepped impedance resonator.

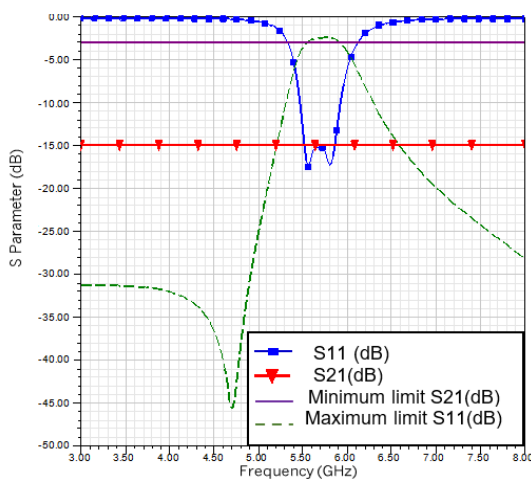

Figure 7. S parameters of Bandpass filter stepped impedance resonator
A quarter wavelength bandpass filter stepped impedance resonator has been adopted to miniaturize the occupied filter area. This approach involves a ring slot in the bottom ground plane that is the edge of the microstrip antenna without adding any resonators and space[24][25]. A novel approach is also proposed to get $5.8 \mathrm{GHz}$ working frequency with wideband rejected, band range of $\mathrm{S}$ parameters is $320 \mathrm{MHz}$, rang of isolation is $300 \mathrm{MHz}$, and the serve of range optimum frequency filter is $100 \mathrm{MHz}$.

To determine, the electromagnetic structure is good work we must identify the impedance output. the impedance output can be shown with a Smith chart graphic[26][27]. Figure 13 has shown the impedance output of the integrated rectangular cutting corners double edge microstrip antenna and bandpass filter stepped impedance resonator:

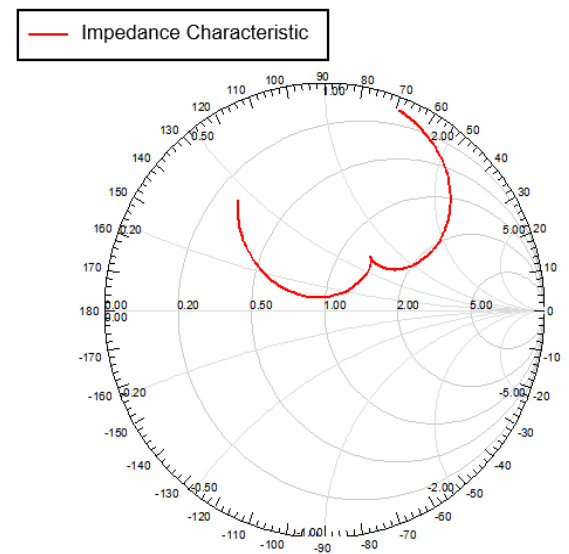

Figure-7. The characteristic impedance of $5.8 \mathrm{GHz}$ integrated rectangular cutting corners double edge microstrip antenna and bandpass filter stepped impedance resonator

\section{CONCLUSION}

In this research, a compact $5.8 \mathrm{GHz}$ integrated rectangular cutting corners double edge microstrip antenna and bandpass filter stepped impedance resonator, easy to implement and cheap material that has epoxy laminate with $\varepsilon r=4.4$ have been defined. This fabrication of the antennae has a transmission line $\lambda / 4$ connected with via hole on the resonator with working frequency is $5.8 \mathrm{GHz}$ and connected with $5.8 \mathrm{GHz}$ Bandpass filter. The purposed microstrip antenna with a feeding network on the backside system has pattern radiation is directional with a high gain of $6.29 \mathrm{dBi}$, and the axial ratio level is circular polarization. the network system on feeding microstrip circuit consists of a bandpass filter stepped impedance resonator feed has an effective frequency range on $100 \mathrm{MHz}$ of single inputs from the via hole. The whole has the dimension $40 \mathrm{~mm} \times 40 \mathrm{~mm}$ and the entirety characteristic is a good implementation.

\section{REFERENCES}

[1] J. W. Sanders, J. Yao, And H. Huang, "Microstrip Patch Antenna Temperature Sensor," Ieee Sens. J., 2015, Doi: 10.1109/Jsen.2015.2437884.

[2] I. Mujahidin, S. H. Pramono, And A. Muslim, "5.5 
Ghz Directional Antenna With 90 Degree Phase Difference Output," 2018, Doi: 10.1109/Eeccis.2018.8692872.

[3] I. Mujahidin, R. Yuwono, And A. Mustofa, "Rancang Bangun Rectifier Antenna Mikrostrip Ufo Pada Frekuensi Ultra Wideband (Uwb) Sebagai Pemanen Energi Elektromagnetik," J. Mhs. Teub, Vol. 3, No. 2, 2015.

[4] M. Chmiel Et Al., "Lte-Advanced," In Lte For Umts: Evolution To Lte-Advanced: Second Edition, 2011.

[5] D. F. C. Kusuma, D. A. Prasetya, F. Kholid, And I. Mujahidin, "Evaluasi Database Senjata Untuk Sistem Keamanan Menggunakan Fuzzy Logic," Jasiek (Jurnal Apl. Sains, Informasi, Elektron. Dan Komputer), Vol. 1, No. 2, Pp. 111-116, 2019.

[6] R. Yuwono, I. Mujahidin, A. Mustofa, And Aisah, "Rectifier Using Ufo Microstrip Antenna As Electromagnetic Energy Harvester," Adv. Sci. Lett., 2015, Doi: 10.1166/Asl.2015.6574.

[7] C. A. Balanis, Modern Antenna Handbook. 2007.

[8] I. Mujahidin, "Smart Transducers," Http://Antenapropagasi.Blogspot.Com/2018/11/Sma rt-Transducers.Html. 2018.

[9] R. Yuwono And I. Mujahidin, "Rectifier Using Uwb Microstrip Antenna As Electromagnetic Energy Harvester For Gsm, Cctv And Wi-Fi Transmitter," J. Commun., 2019, Doi: 10.12720/Jcm.14.11.10981103.

[10] E. Endrayana, D. H. S. Wahyuni, N. Nachrowie, And I. Mujahidin, "Variasi Ground Plane Antena Collinear Pada Pemancar Telivisi Analog Dengan Frekuensi Uhf 442 Mhz," Jasiek (Jurnal Apl. Sains, Informasi, Elektron. Dan Komputer), Vol. 1, No. 2, Pp. 149-156, 2019.

[11] I. Mujahidin And P. S. Arinda, "Antena Compact Double Square Marge 2, 6ghz Dengan Output Perbedaan Fase 90 Derajat Untuk Aplikasi Lte," Jeecae (Journal Electr. Electron. Control. Automot. Eng., Vol. 4, No. 2, Pp. 273-278, 2019.

[12] B. F. Hidayatulail And I. Mujahidin, "Potential Of 77, $78 \mathrm{Mw}$ Red Diode Laser For Photodynamic," Jeemecs (Journal Electr. Eng. Mechatron. Comput. Sci., Vol. 2, No. 2, 2019.

[13] I. V. Robbyvalentino, N. Nachrowie, D. W, And Mujahidin, "Rancang Bangun Sistem Penilaian Kesegaran Jasmani A Di Jajaran Tni-Ad Berbasis Rfid," Jasiek (Jurnal Apl. Sains, Informasi, Elektron. Dan Komputer), Vol. 2, No. 1, Pp. 98-106, 2020.

[14] A. E. Pambudi, L. Maajid, J. Rohman, And I. Mujahidin, “Aplikasi Penggunaan Joystick Sebagai Pengendalian Remote Control Weapon Station (Rcws) Senjata Mesin Ringan (Smr)," Jasiek (Jurnal Apl. Sains, Informasi, Elektron. Dan Komputer), Vol. 1, No. 2, Pp. 98-105, 2019.

[15] I. Mujahidin, D. A. Prasetya, A. B. Setywan, And P. S. Arinda, "Circular Polarization 5.5 Ghz Double Square Margin Antenna In The Metal Framed Smartphone For Sil Wireless Sensor," In 2019 International Seminar On Intelligent Technology And Its Applications (Isitia), 2019, Pp. 1-6.

[16] R. N. Simons, D. G. Hall, And F. A. Miranda, "Rf Telemetry System For An Implantable Bio-Mems Sensor," 2004, Doi: 10.1109/Mwsym.2004.1338841.

[17] I. Mujahidin, "Directional Couplers," Http://Antenapropagasi.Blogspot.Com/2018/11/Dir ectional-Couplers.Html, No. 1. 2018.

[18] J. Lasmono, A. P. Sari, E. Kuncoro, And I.
Mujahidin, "Optimasi Kerja Peluncur Roket Pada Robot Roda Rantai Untuk Menentukan Ketepatan Sudut Tembak," Jasiek (Jurnal Apl. Sains, Informasi, Elektron. Dan Komputer), 2019, Doi: 10.26905/Jasiek.V1i1.3149.

[19] D. A. Ayubi, D. A. Prasetya, And I. Mujahidin, "Pendeteksi Wajah Secara Real Time Pada 2 Degree Of Freedom (Dof) Kepala Robot Menggunakan Deep Integral Image Cascade," Cyclotr. J. Tek. Elektro, Vol. 3, No. 1, 2020.

[20] I. Mujahidin, D. A. Prasetya, Nachrowie, S. A. Sena, And P. S. Arinda, "Performance Tuning Of Spade Card Antenna Using Mean Average Loss Of Backpropagation Neural Network," Int. J. $A d v$. Comput. Sci. Appl., 2020.

[21] C. E. Balanis, "Antenna Theory: Analysis And Design, 3rd Edition - Constantine A. Balanis," Book. 2005, Doi: 10.1049/Ep.1982.0113.

[22] I. Mujahidin, "Directional $1900 \mathrm{Mhz}$ Square Patch Ring Slot Microstrip Antenna For Wcdma," Jeemecs (Journal Electr. Eng. Mechatron. Comput. Sci., 2019, Doi: 10.26905/Jeemecs.V1i2.2626.

[23] I. Mujahidin And B. F. Hidayatulail, "2.4 Ghz Square Ring Patch With Ring Slot Antenna For Self Injection Locked Radar," Jeemecs (Journal Electr. Eng. Mechatron. Comput. Sci., Vol. 2, No. 2, 2019.

[24] I. Syrytsin, Shuai Zhang, And G. F. Pedersen, "Finger Ring Phased Antenna Array For 5g Iot And Sensor Networks At 28 Ghz," 2018, Doi: 10.1049/Cp.2018.0423.

[25] D. A. Prasetya, A. Sanusi, G. Chandrarin, E. Roikhah, I. Mujahidin, And R. Arifuddin, "Small And Medium Enterprises Problem And Potential Solutions For Waste Management," J. Southwest Jiaotong Univ., Vol. 54, No. 6, 2019.

[26] W. Hong, K. Baek, Y. Lee, And Y. G. Kim, “Design And Analysis Of A Low-Profile $28 \mathrm{Ghz}$ Beam Steering Antenna Solution For Future 5g Cellular Applications," 2014, Doi: 10.1109/Mwsym.2014.6848377.

[27] D. A. Prasetya, A. Sanusi, G. Chandrarin, E. Roikhah, I. Mujahidin, And R. Arifuddin, "Community Culture Improvisation Regarding Waste Management Systems And Per Capita Income Increase," J. Southwest Jiaotong Univ., Vol. 54, No. 6, 2019 .
Copyright @2016 PROtek : Jurnal Ilmiah Teknik Elektro lisensi Creative Commons Attribution 4.0 International Licens 